\title{
TRANSPORT AND GEOGRAPHIC ORGANIZATION OF SOCIETY: CASE STUDY OF CZECHIA
}

M. Marada: Transport and geographic organization of society: Case study of Czechia. Geografie-Sborník CGS, 113, 3, pp. 285-301 (2008). - This article seeks a solution to the mutual association of transport and the complex hierarchy of selected Czech settlements. Evaluation of 144 centres of micro-regional and separately of 12 centres with meso-regional importance was based on public and automobile transport and complex importance indicators. The mutual "closeness" of hierarchies according to the various indicators used was evaluated by a correlation analysis, the level of hierarchization is distinguished with help of rang size rule.

KEY WORDS: hierarchy - public transport - automobile transport - complex importance settlement centres.

This article is a result of research project No. 205/05/P216 Transport and geographic organization of the society under the Grant Agency of the Czech Republic. The author thanks the Agency for its kind support.

\section{Introduction}

The frequency of studies focused on transport issues, in current international geographic literature, has increased lately. This is due, not only to the urgency of transport issues observed in everyday life, but also to the evident return of quantitative methods into research on these issues, as well as to a certain approximation of processes used by technical sciences, which predominantly study transport issues. Also in the field of transport geography we can confirm the Hampl's often repeated opinion (e.g. Hampl 2004) that research is aimed more at studying the "geographic organization of development" and less at necessary, generalizing studies on the "development of geographic organization". Hampl further develops this idea by affirming that in the first case "it is about searching for and differentiating the significance of geographic factors conditioning the differentiation of social and economic development..." (p. 206) and in the second case "...it is necessary to seek answers to these questions: how does the character of concentration processes change, how does a settlement hierarchy develop, how does the core function (in the sense of core vs. periphery) of cities change in terms of both overall extent and function, or rather quality." (p. 206).

From the discipline of transport geography, for example, classical geographic studies on the regional differentiation of transport infrastructure quality and its relation to other socio-geographic characteristics can be included in the first type of studies. For instance, Marada (2003a), when comparing Czech border regions with the interior, showed that in Czechia's 
specific circumstances, higher quality transport infrastructure in a region does not necessarily correspond to better economic conditions. Research also frequently focuses on urgent transport problems in cities (especially competition between individual automobile transport and public transit - see, for example, Marada 2006; Ouředníček 2006; de Palma, Rochat 2000 and others) or, in contrast, on transport in peripheral, rural areas (accessibility in connection with social exclusion of certain groups of the population - e.g. Nutley 1998; Farrington, Farrington 2005; McDonagh 2006; Marada, Hudeček 2006 and Květoň 2006). At present, transport is primarily conceived as a significant contributing factor in the differentiation of regional development (e.g. Bruinsma, Rietveldt 1998; Bryan et al. 1997; Vondráčková 2006; Lehovec 2003 etc.) and numerous studies in this field, at least in the interpretation of their results, deal with the second type of problems described by Hampl. Thus, it becomes necessary to specify the questions, with which Hampl generally characterized studies of this second type (the "development of geographic organization"), in this case, in terms of transport issues:

- How and to what degree does transport influence the concentration of job opportunities?

- How does transport contribute to intensification of the settlement hierarchy? Is its role in this process increasing?

- Does a good transport system increase the regional role of cities and promote the spatial enlargement of their hinterland?

- How does time accessibility support the competition and cooperation of centres?

The above examples of questions illustrate three spheres of problems, into which the discussed relation of transport to changes in the geographic organization of society can be subdivided in a simplified way. Transport factors have a clear impact on changes in the concentration of job opportunities and progressive activities, i.e. on processes leading to the intensification of the settlement hierarchy. In these processes, transport plays a significant role, for example, by improving time accessibility through the development of transport networks or by improving the quality of transport services in city centres. The respective transport significance of the various centres - both in terms of their position in transport networks as well as the intensity of transport - is however the result of relations between the centre and its micro-regional hinterland along with relations existing between centres themselves, which are expressed within the various regional levels of centres (e.g. the contact of micro-regional centres with their relevant, superior meso-regional centre), but also between centres at the same level (e.g. between meso-regional centres). Hierarchically higher centres, therefore, cumulate their functions (including transport functions) in varied regional arrangements. The two basic realms of the problem discussed here, outline the issue of relations among centres and core-hinterland relations; a third realm is the inherent relation between the resulting transport and complex hierarchy of centres. In the subsequent text, the levels described are only briefly discussed, due to the limited extent of this article. The third sphere is empirically evaluated with the example of the hierarchy of the main centres of settlement in Czechia. 


\section{Relations among centres and between centre and hinterland}

The mutual interconnection of significant centres of settlement by transport routes allows for the development of both competitive processes, i.e. "growth of stronger centres to the detriment of weaker centres", as well as cooperative processes, i.e. territorial specialization, diffusion of progressive activities from core regions to peripheral areas, etc. In this sense, transport systems can contribute to the intensification and weakening of the settlement hierarchy. Processes of concentration and cooperation are, however, difficult to evaluate considering the present state of statistics.

It is clear that the mutual time accessibility of core settlement areas, which facilitates or, on the contrary, impedes their contact, plays an indispensable role in the intensity of their interactions. Increasing intensities of transport relations with deceasing distance between settlements have been proven by numerous "classical" models, for instance, the so-called distance-decay or gravitational models (see e. g. Hagget, Chorley 1969; Luoma et al. 1993 etc., from Czech authors e. g. Rehák 1992 or Rölc 2004). The growth of cooperation or competition among centres is manifested by a variety of elements, including an increase of transport between centres, as well as a shortening of transit time, which is often related to quality improvements in the transport network. Development of better transport infrastructure is, in fact, called for by the needs of the strongest centres. In the case of Czechia, however, the development of networks lags significantly behind the intensity of transport contacts among centres, because of the great financial costs involved in infrastructure construction (see also studies by Marada 2006 evaluating the relation of the horizontal and vertical position of centres in terms of their complex size).

The issue of the role of transport in the core - hinterland relationship can be divided into two levels that are, of course, closely interconnected. The first is the impact of the transport infrastructure's quality on the growth of the city's (or town's) significance as a centre attractive for investment allocation and for new progressive activities connected with the availability of job opportunities. Naturally, the importance of transport factors is not considered the most important in this case. For instance, Blažek points out that the distribution of firms in the progressive tertiary sector in Czechia, during the 1990 s, show no apparent relation, for example, between the size of centres, the level of socio-economic development of the districts or their geographic position, verifying the significant influence of subjective factors such as entrepreneurial incentive or the existence of governmental supporting programmes. In this way, Blažek builds on the opinion of Dicken and Lloyd (1992, quoted in Blažek 2001) that the great concentration of firms in the progressive tertiary sector "...into central regions, which, in developed countries, is usually similar in principle to the distribution of the headquarters of large firms, is due to the irreplaceablility of personal contact when solving certain problems" (p. 238). The influence of the presence of an airport in the region on the localization of progressive tertiary firms is difficult to prove. It is true that a significant portion of these firms are transnational, creating high demands for contact with supervising or cooperating branches in foreign countries. In addition, metropolitan areas regularly have international airports and strengthening connections with a required destination is a matter of adapting supply to demand. Consequently, in this sense, it is more correct to evaluate the development of 
airport efficiency in the context of other air transport centres. Simply put, the position of an airport in international ranking lists does not sufficiently determine the degree of the airport's impact as a localization factor and it is, again, only one of several contributing localization factors.

In terms of evaluating motorways as factors of local and regional development, authors agree almost unanimously that the presence of a motorway is only one - and certainly not a sufficient - condition for the development of adjacent regions. Probably the most detailed study of this nature in Czechia was carried out by Jeřábek, Marada (2003) and Vondráčková (2006) on a segment of the D8 motorway between Prague and Lovosice. The observations revealed that the presence of this motorway encouraged the construction of residential areas as well as the placement of certain types of economic activities, primarily in hinterland areas near Prague and to a lesser degree around Lovosice. In the Prague suburban area, such activities simply represented a transfer of existing economic activities to the motorway. Motorways encourage the territorial concentration of certain types of activities (logistics centres, shopping centres, etc.) which, of course, could be a mere spatial redistribution of previously existing activities (Bruinsma, Rietveldt 1998, speak about the distribution effect of transport infrastructure). An overview of significant, recent case studies from the Anglo-Saxon region is presented in an article by Preston (2001). For the most part, the studies listed in Preston's article failed to prove the existence of a significant impact - or showed only a small impact - of a motorway or highspeed railway on improvements in the employment rate. Preston, however, urges geographers not to be needlessly sceptical in their conclusions concerning the impact of transport on the development of localities and regions and he offers a provocative question: "Do we really believe that, for example, the development of the motorway network in Britain over the last forty years or so has had no impact on socio-economic activities?" (Preston 2001 , p. 22). Even though all of these findings represent conclusions of localized case studies, the conformity of their results enables one to make a claim that the main impulse for motorway construction is not to support the development of economically weaker regions (as decision-makers often proclaim), but rather the need of centres at a higher level to become interconnected with faster and larger infrastructure. Although those deciding on such construction may not be aware, the main driving force behind quality improvements to networks is pressure from general regional development.

The second, but corresponding, level in the discussion of the role of transport in the contact of a centre with its hinterland is the view of transport as a means enabling the mobility of inhabitants, or rather a means of fulfilling the need to commute to centres with a concentration of job opportunities. Analyzing this connection is difficult primarily because of the uncertain causality of both phenomena. Would the central role of mesoregional centres, or of Prague for that matter, be as high without a functional transport system? Would job opportunities (in Prague, for instance) increase if there were an insufficient labour force, because of difficulties commuting, among other problems? Or does the number of job opportunities increase regardless of the availability of labour on the market? Does the market rely upon the attractiveness of working in centres and on the adaptation of prospective employees? These questions are intentionally formulated in a rather extreme manner to stress the relationship being discussed. It is probable that the indicated relationship applies in both directions. Demand 
for jobs, in Prague for example, along with existing deformations in the housing market (inland migration is to a certain degree replaced with daily and even non-daily commuting to work - see, for example, Čermák 2001, etc.) create pressure on transport services for commuting to Prague. On the other hand, progressive economic sectors, especially, develop in response to economic needs and are allocated to Prague as Czechia's leading settlement centre. The higher income level of employees at such firms enables them to lease apartments directly in the locality and, consequently, to not be dependent on commuting.

It is generally presumed that the intensity of commuting to a centre is tied to the widely perceived, transport availability (see also the gravitational model mentioned above). Even from a brief comparison of the sociogeographic regionalization of Czechia in 1991 and 2001 (Hampl, Müller 1996; Hampl 2005) it is clear that enlargement of the commuting hinterland of micro-regional centres or, depending on the situation, enlargement of metropolitan areas, occurred in many cases in the direction of important surface roadways. This is because commuting time is clearly a more important deciding factor than is the actual distance (in kilometres) in the daily commuting habits of the population. In the case of Prague as the strongest centre, it is evident that its significance as a commuting centre (to work or to school) has expanded, in terms of area, between 1991 and 2001, mainly along important transport corridors - see also Hampl 2004), primarily motorways and important railways. By 2001, in comparison with 1991, a total of eight meso-regional centres out of eleven (these include all Czechia's regional capitals, with the exception of Prague and Jihlava) newly oriented themselves towards Prague as did 19 micro-regional centres (out of 132). In a study mentioned above, Vondráčková (2006) used a comparison of data from the 1991 and 2001 censuses to show that the D8 motorway has not promoted a reorientation of the strongest directions of commuting to work, which have remained focused on micro-regional centres. In the majority of concerned municipalities, however, the second strongest commuting direction has been replaced by easily accessible Prague.

It remains true, however, that the high-order transport network, which is, as a rule, the conveyor of improved time accessibility, has not changed significantly in the greater Prague area during the period of time between censuses (1991-2001). Some small, additional segments of the D8 motorway were completed and the railway No. 011 in the direction of Kolin (which is part of rail corridor I) received technical improvements. In addition to the time aspect, transport expenses, closely related to the trip's actual kilometre distance, are also an important factor in the decision process for residents about the goal of their commute. Beginning with a certain limit, daily commuting is replaced with non-daily movements (see also the new orientation of relatively inaccessible and economically poorly developed territories towards Prague in the Hampl's study mentioned above - the areas of Jeseníky mountains and Orlické hory mountains for example). Not only the time accessibility of commuting centre, but also its attractiveness as a place to work plays an important role in the spatial organisation of population movements. A commuting region, therefore, is a result of the interference of these two factors.

Bruinsma, Rietveld (1998) conclude that the impact of transport infrastructure on the labour market and commuting manifests itself both through the arrival of new firms in the region as well as through a possible 
decrease in the productivity of local enterprises due to increased competition from neighbouring, more developed regions. Without a flexible labour force, i.e. without workers willing to attend retraining courses or to commute longer distances to work, negative impacts of a new transport corridor could significantly outweigh those on the positive side. The conditioning impact of transport is, in terms of the concentration of job opportunities, rather insignificant, because the creation of firms in progressive economic sectors is influenced by a series of additional factors, including the flexibility of human resources, the hierarchical importance of the centre in question, its geographic position, etc. Transport can, however, influence the quantity of the available labour force, because the volume of residents daily commuting to the core is significantly limited by the time accessibility of the centre. This limiting function of transport should, however, be further verified empirically.

\section{Relation between the transport and the complex-settlement hierarchy}

The aspects discussed in the preceding text have a resulting impact on the differentiation of centres in terms of their complex importance and their transport importance and thus, they also have an impact on relationships and conformity of both types of hierarchies. The following summary focuses on examining the mutual conditionality of both hierarchies and results in a determination of prerequisites for the subsequent empirical section.

First it should be stressed that transport is a manifestation of the mobility of the human population and their spatial differentiation is, naturally, strongly tied to the concentration of population and to its activities. The intensity of transport in centres is therefore connected with the population size of cities/towns. It is influenced not only by the population living in the centres, but also by those commuting to this centre for job opportunities, i.e. to the extent of the centre's hinterland and its relations with other centres. In this sense, we can expect a mutual size conditionality of transport and complex-settlement hierarchies. This conditionality is certainly positive, has corresponding development tendencies and the ascertained association of transport importance of centres with their complex significance will probably be very close.

A connected question is the causality of the interaction between the settlement hierarchy and the transport hierarchy. The impact of rail transport on the development of settlements in the 19th century is sufficiently recognised. Many examples of medium-size cities, whose importance has noticeably increased after being connected to a railway, can be given. Such cities have also taken over the role of more important historical cities, which have been relegated to a worse position in terms of transport (see, for example, Kolín - Kutná Hora or Pardubice - Chrudim). Connection of a centre to a railway led, in certain cases, even to gaining administrative (i. e. governing) functions. Also, current development of the motorway network is conditioned by a need to connect the most important centres of the national and transnational hierarchy. Its growth impact is, however, more evident in the strongest centres and less so in weaker, intermediate centres. Both these simple examples prove that, in addition to the mutual influences between settlement and the transport systems, there is 
also a certain difference between the two main types of transport infrastructure in our country. The roadways, as a more flexible and historically younger network, more closely reflect the present hierarchy of settlements, while the earlier developed rail network arose from the economic needs of the industrial era, its network is, in general, sparser and its maximum extent has already been reached. Therefore railways have "out of necessity" a linear character and are used more for long-distance transport. This very position, the distinct transport position of a centre in both main types of transport networks is, especially in the case of the rail network, a frequent cause of differences in the transport and geographic position of settlements and consequently a disturbance of the concordance of both evaluated hierarchies. Large differences arise, therefore, mainly in the case of smaller centres, the position of which in both types of transport networks is not balanced and which frequently "profit" from their position on transport lines connecting hierarchically more important nodes.

The position of a centre in transport networks is also manifest in the structure of transport in the centre itself, specifically as a ratio of train and bus connections and also as a ratio of international, long-distance and local connections. Especially smaller settlements at important transport lines can, in this way, have significantly better transport services. Transport conditions in a centre in terms of the structure of transport means are to a certain degree conditioned by the character of the centre's hinterland. Earlier studies (e. g. Květoň 2006, Seidenglanz 2007, Kraft 2007) make it clear that sparsely populated territories are more poorly served by public transport and are more dependent on individually ensuring accessibility with privately owned automobiles. These tendencies, however, influence the transport typology of centres rather than their hierarchization. It is, of course, clear that the horizontal transport position of a centre in transport networks influences its vertical position, the transport importance in terms of transport intensity, for example.

Hypotheses on the relation between transport and complex settlement hierarchy of centres can be established as follows. The relation between transport and complex settlement hierarchy of centres of settlement in Czechia will be observed both in terms of the degree of hierarchization of the observed group of centres according to various characteristics and also in terms of the degree of concordance of transport hierarchies with the complex hierarchy. Because of the conditionality of size mentioned above, we can assume a strong association of the hierarchies of both types exists. Partial transport systems (bus, automobile and rail transport) will, of course, be associated with the complex hierarchy to a different degree. In light of planned, "all-inclusive" bus services and the weaker determination of road transport by networks, closer relations will be found in bus and automobile transport than in rail transport, which, due to their dependence on the historical rail network, manifest a somewhat "linear" differentiation and a stronger focus on long-distance transport. For similar reasons, out of the transport characteristics, the level of hierarchy of automobile and bus transport will most closely approximate the complex hierarchy. 


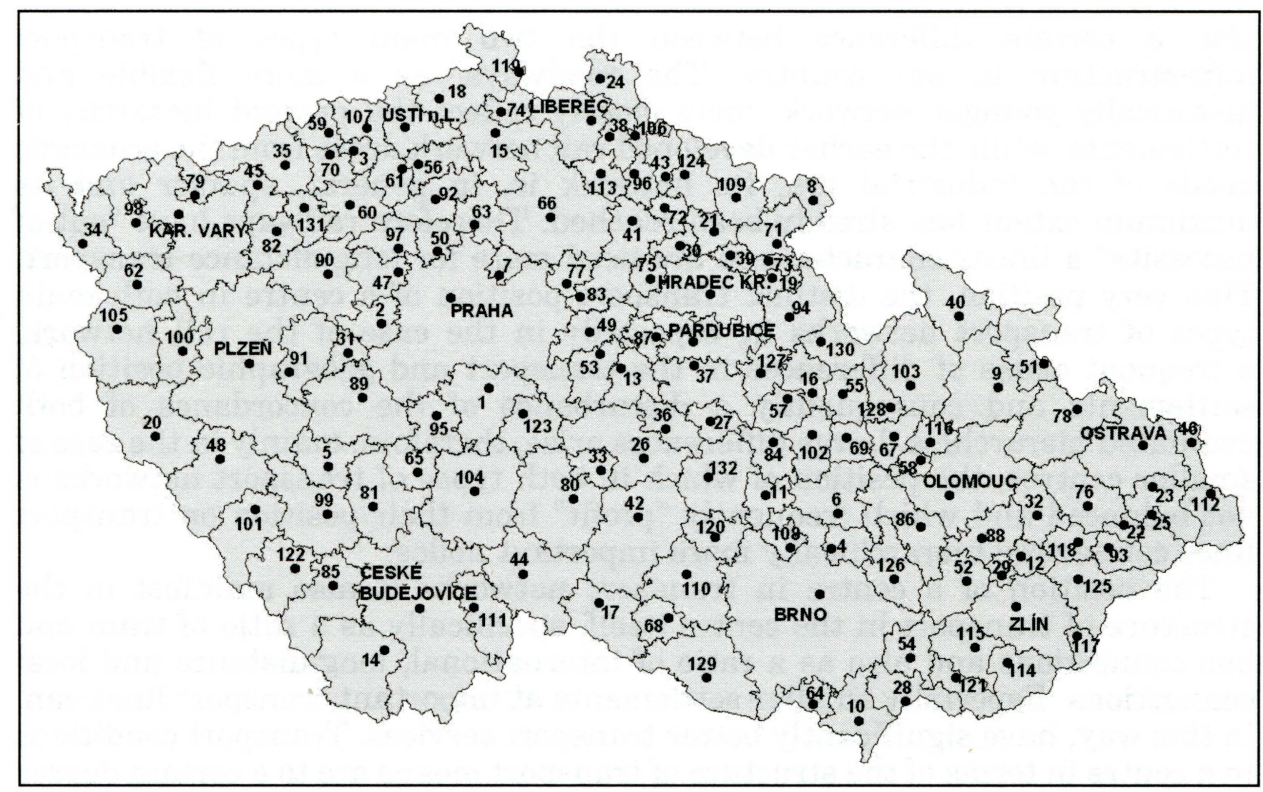

Fig. 1 - Socio-geographic micro-regions and its centres in Czechia (2001). Centres of higher importance - macro-regional (Prague) and meso-regional one (regional capitals excerpt Jihlava) - are described. Other centres of micro-regional importance (in alphabetical order): 1-Benešov, 2-Beroun, 3-Bílina, 4-Blansko, 5-Blatná, 6-Boskovice, 7-Brandýs nad Labem-Stará Boleslav, 8-Broumov, 9-Bruntál, 10-Břeclav, 11-Bystřice nad Pernštejnem, 12-Bystřice pod Hostýnem, 13-Č́slav, 14-Český Krumlov, 15-Česká Lípa, 16-Česká Třebová-Ústí nad Orlicí, 17-Dačice, 18-Děčín, 19-Dobruška, 20-Domažlice, 21-Dvůr Králové nad Labem, 22-Frenštát pod Radhoštěm, 23-Frýdek-Místek, 24-Frýdlant, 25-Frýdlant nad Ostravicí, 26-Havlíčkův Brod, 27-Hlinsko, 28-Hodonín, 29-Holešov, 30-Hořice, 31-Hořovice, 32-Hranice, 33-Humpolec, 34-Cheb, 35-Chomutov, 36-Chotěboř, 37-Chrudim, 38-Jablonec nad Nisou, 39-Jaroměř, 40-Jeseník, 41-Jičín, 42-Jihlava, 43-Jilemnice, 44-Jindřichův Hradec, 45-Kadaň, 46-Karviná, 47-Kladno, 48-Klatovy, 49-Kolín, 50-Kralupy nad Vltavou, 51-Krnov, 52-Kroměříž, 53-Kutná Hora, 54-Kyjov, 55-Lanškroun, 56-Litoměřice, 57-Litomyšl, 58-Litovel, 59-Litvínov, 60-Louny, 61-Lovosice, 62-Mariánské Lázně, 63-Mělník, 64-Mikulov, 65-Milevsko, 66-Mladá Boleslav, 67-Mohelnice, 68-Moravské Budějovice, 69-Moravská Třebová, 70-Most, 71-Náchod, 72-Nová Paka, 73-Nové Město nad Metují, 74-Nový Bor, 75-Nový Bydžov, 76-Nový Jičín, 77-Nymburk, 78-Opava, 79-Ostrov, 80-Pelhřimov, 81-Písek, 82-Podbořany, 83-Poděbrady, 84-Polička, 85-Prachatice, 86-Prostějov, 87-Přelouč, 88-Přerov, 89-Příbram, 90-Rakovník, 91-Rokycany, 92-Roudnice nad Labem, 93-Rožnov pod Radhoštěm, 94-Rychnov nad Kněžnou, 95-Sedlčany, 96-Semily, 97-Slaný, 98-Sokolov, 99-Strakonice, 100-Stř́ibro, 101-Sušice, 102-Svitavy, 103-Šumperk, 104-Tábor, 105-Tachov, 106-Tanvald, 107-Teplice, 108-Tišnov, 109-Trutnov, 110-Třebíč, 111-Třeboň, 112-Třinec, 113-Turnov, 114-Uherský Brod, 115-Uherské Hradiště, 116-Uničov, 117-Valašské Klobouky, 118-Valašské Meziřičí, 119-Varnsdorf-Rumburk, 120-Velké Meziříćí, 121-Veselí nad Moravou, 122-Vimperk, 123-Vlašim, 124-Vrchlabí, 125-Vsetín, 126-Vyškov, 127-Vysoké Mýto, 128-Zábřeh, 129-Znojmo, 130-Žamberk-Letohrad, 131-Žatec, 132-Ždár nad Sázavou.

Source: Hampl 2005

\section{Empirical analysis of settlement centres' hierarchization}

\subsection{Methods of research}

The main methodological problem when studying transport and the complex importance of centres and their relations is to determine a monitored 
group of centres and, at the same time, to choose representative indicators characterizing the transport and complex importance of centres.

Settlements were chosen for monitoring on the basis of the socio-geographic regionalization carried out by Hampl according to the Population and Housing Census from 2001 (Hampl 2005). This paper outlines, according to the prevailing commuting orientation of the population to work and school, a total of 144 micro-regional centres, out of which were determined (on the basis of their mutual relations) 11 centres of meso-regional importance (these include all Czechia's regional capitals, with the exception of Prague and Jihlava) and one centre of macro-regional importance - Prague (see Fig. 1). Four of these selected centres have a double core and were therefore agglomerated (Česká Třebová-Ústí nad Orlicí, Zlín-Otrokovice, ŽamberkLetohrad and Rumburk-Varnsdorf).

The selection of relevant indicators was conducted in an effort to characterize both the size and quality of transport services in the centres. Consequently, both individual and public transports were monitored. Moreover, data in public transport timetables enable distinguishing local and long-distance (among centres) connections which, as a more selective segment of transport, deepen the transport hierarchy. The importance or extent of public rail and bus transport in centres was evaluated according to the number of connections departing from the centre on Wednesday 24 May 2006. In this way, the availability of public transport on working days is expressed. This simple indicator has a limited informative value, because data on the actual use of these connections (occupancy level) are not available for such an extensive group; however, because of the interconnection of transport supply and demand in larger centres this index can be considered sufficiently representative. These data were taken from the electronic IDOS timetable (CD ROM version from the firm CHAPS Brno). Long-distance train connections (labelled LONGTRAIN) were determined as the sum of express, fast and rapid train connections, the category of long-distance bus connections is labelled $L O N G B U S$. The remaining connections are of a local nature and are marked as LOCALTRAIN (local train connections), or LOCALBUS (local bus connections). In light of the greater importance of long-distance connections in the hierarchical position of centres and also due to greater capacity (and at the same time a lower number) of train connections, different weights were utilised when determining the total important transport characteristics of these connections: aggregate passenger rail transport TRAIN was defined as the sum of long-distance train connections (LONGTRAIN) multiplied by three plus the number of other (local) connections (LOCALTRAIN); the aggregate for bus transport: BUS, was constructed in the same manner (i.e. $3 \times L O N G B U S+1 \times L O C A L B U S$ ). The total transport hierarchization of centres in terms of public transport was then carried out with a summarizing transport aggregate (PUBLIC) TRANSPORT, determined-again because of higher capacity, but lower frequency of connections-as the sum of three times the value of the TRAIN aggregate plus the value of the $B U S$ aggregate.

The second method used to evaluate the transport importance of centres was enumerating the transport load of centres in terms of automobile transport intensity (Hůrský 1978, discusses the "attractiveness" of towns). Results from the census of transport frequency on main roads in 2005, conducted every five years by the Road and Motorway Directorate of the Czech Republic, were used for this evaluation. The statistic used is, in fact, 
the sum of all transport volume measured at census points situated in the proximity of the centre, i.e. a total amount of vehicles entering or departing from the centre in the course of a 24 hour period on an "average" day (for more about methods, see the website of the Road and Motorway Directorate, www.rsd.cz). The structure of the traffic stream was also monitored, but individual categories were not analysed, as this would be very time demanding. Private cars represent more than three quarters of the traffic stream (75.6\% in 2005) in the group of centres. The majority of the remaining volume consisted of lorries of all weight categories and marginal amounts of motorcycles and bikes. Unfortunately, the available database does not allow for the exclusion of bus transport, which is included in the evaluation through timetables described above, but their frequency is negligible and does not influence the analyses carried out. The transport importance of centres in terms of road transport intensity was enumerated for 2005, due to the availability of data in five-year period, and labelled AUTO.

Finally, an index of complex size of centres (CS) for the year 2001, also taken from Hampl's publication (2005), was used to evaluate the complex importance of settlement centres. Construction of the index is based on the number of residents living in the area and the number of job opportunities located there, meaning that it combines the residential and labour functions of the centre and makes them relative with regard to the national system.

Hierarchization of the various groups is evaluated with the help of basic characteristics from descriptive statistics as well as by employing the rank size rule (Auerbach 1913, quoted in Hampl, Gardavský, Kühnl 1987), used here as comparative model for distinguishing the level of hierarchization. Calculations are carried out here only for the first five defined categories, that is, up to the 98th unit. In this way, the most significant, upper and middle part of the hierarchy of centres is included. Hierarchization is evaluated in a double manner - both by the degree of diversification of the centre and by its degree of concordance.

\subsection{The results: State, development and implications of the transport and complex hierarchization of centres}

Even in the early comparison of average, median and modal values of the monitored groups, a varied level of the asymmetric (hierarchical) differentiation of the groups of centres according to the monitored characteristics was already evident. The hierarchization of the groups is better characterized by a comparison with the rule of the size sequence of cities (Tab. 1). As presumed, these values also verify the sequence predicted above concerning the level of hierarchization of a group according to the selected characteristics. The overall transport hierarchy of centres in terms of public transport (according to the TRANSPORT index) has developed to a much weaker degree than the most developed complex settlement hierarchy. This is caused partly by the necessity to ensure spatially inclusive transport services (after falling to a certain size of settlement, the quantity of departures practically do not decrease with size) and partly by the limited explanatory value of the data used, as discussed above, because the number of connections does not accurately represent the volume of passengers. We can further state that centres have naturally higher levels of hierarchization 
Tab. 1 - Size hierarchization of centres according to transport indicators and their complex size (size of the first centre $=100.00$ )

\begin{tabular}{|l|c|c|c|c|c|c|c|c|c|}
\hline Order & $\begin{array}{c}\text { LONG- } \\
\text { TRAIN }\end{array}$ & $\begin{array}{c}\text { LOCAL- } \\
\text { TRAIN }\end{array}$ & $\begin{array}{c}\text { LONG- } \\
\text { BUS }\end{array}$ & $\begin{array}{c}\text { LOCAL- } \\
\text { BUS }\end{array}$ & TRAIN & BUS & $\begin{array}{c}\text { TRANS- } \\
\text { PORT }\end{array}$ & AUTO & CS \\
\hline $1^{\text {st }}$ & 100.00 & 100.00 & 100.00 & 100.00 & 100.00 & 100.00 & 100.00 & 100.00 & 100,00 \\
$2^{\text {nd }} 4^{\text {th }}$ & 200.00 & 136.30 & 104.80 & 157.80 & 166.00 & 112.30 & 125.00 & 127.74 & 73,62 \\
$5^{\text {th }}-12^{\text {th }}$ & 351.70 & 286.10 & 121.50 & 262.70 & 322.50 & 180.60 & 221.20 & 170.16 & 62,64 \\
$13^{\text {th }}-34^{\text {th }}$ & 543.30 & 600.00 & 209.80 & 466.50 & 533.70 & 313.00 & 380.00 & 296.15 & 83,18 \\
$35^{\text {th }} 98^{\text {th }}$ & 719.20 & 1105.30 & 285.40 & 801.80 & 871.20 & 531.40 & 698.60 & 518.36 & 103,84 \\
\hline $1^{\text {st_98 }}{ }^{\text {th }}$ & 1914.20 & 2227.70 & 821.50 & 1788.80 & 1993.40 & 1237.30 & 1524.80 & 1212.41 & 423.28 \\
$\begin{array}{l}\text { Degree of } \\
\text { hierarchi- } \\
\text { zation }\end{array}$ & 23.76 & 13.86 & 41.36 & 20.33 & 18.93 & 25.14 & 20.86 & 27.96 & 92.83 \\
\hline
\end{tabular}

Notes: 1. Names and description of indicators - see chapter 4.1.

2. Public transport indicator 2006, AUTO 2005, CS 2001.

3 . Degree of hierarchization $=100$ times $\left(\right.$ (size of the $1^{\text {st }}-4^{\text {th }}$ centre $) /\left(\right.$ size of the $13^{\text {th }}-98^{\text {th }}$ centre)), i.e. size of the largest centres in proportion to the size of middle and small centres. Values lower than 100.0 correspond to a lower degree of hierarchization than presumed by the rank size rule, values higher than 100.0 to a higher degree.

4. The line $1^{\text {st }}-98^{\text {th }}$ gives the sum of percentage points from the five categories given. If the size distribution of centres corresponded to the presumption of the rank size rule, the value of this sum would be 500.0. Values lower than 500.0 correspond to a higher degree of hierarchization than presumed by the rank size rule, values higher than 500.0 to the lower degree.

Source: electronic IDOS timetable, Transport census ŘSD ČR, ČSÚ, Hampl 2005

in terms of long-distance transport than local transport. A higher level of hierarchization is manifested by LONGBUS and LONGTRAIN groups as more selective types of connections, which are represented mainly in centres at the top of the list and whose proportion quickly decreases in "lower levels" of the hierarchy. This is the principal difference against groups with a lower level of hierarchization in terms of local rail and bus transport which, due to the necessity of minimal transport services in settlements, practically do not change after falling below a certain size of centres. The majority of smaller centres have only scarce long-distance transport or none at all. In contrast with the complex settlement hierarchy, the developmental extent of the hierarchy of centres in terms of long-distance transport is caused rather by the weak - or even the complete absence of -importance of small centres than by significant differences among large centres.

The lowest degree of hierarchization of centres according to LOCALTRAIN and $L O C A L B U S$ naturally also inhibits the level of hierarchization according to the BUS and TRAIN aggregate characteristics. In spite of a generally low level of hierarchization in terms of transport importance, it is evident that centres have a more developed hierarchy in terms of their available bus services, than in terms of rail transport services. The main reason is the nodal-like concentration of bus transport as well as the linear concentration of rail transport, as mentioned above. In other words, the availability of bus transport in centres is conditioned more by the hierarchy of nodes, while rail transport services available in centres are determined to a greater degree by the hierarchy of transport networks or axes. It is however necessary to stress once again, that the hierarchy of transport axes is primarily conditioned by the hierarchy of nodes and, naturally, most significantly by the hierarchy of nodes of the highest orders. 
Tab. 2 - Paired correlations of transport characteristics and CS - the entire group of 144 centres

\begin{tabular}{|l|c|c|c|c|c|c|c|c|c|}
\hline & $\begin{array}{c}\text { LONG- } \\
\text { TRAIN }\end{array}$ & $\begin{array}{c}\text { LOCAL- } \\
\text { TRAIN }\end{array}$ & $\begin{array}{c}\text { LONG- } \\
\text { BUS }\end{array}$ & $\begin{array}{c}\text { LOCAL- } \\
\text { BUS }\end{array}$ & TRAIN & BUS & $\begin{array}{c}\text { TRANS- } \\
\text { PORT }\end{array}$ & AUTO & CS \\
\hline LONGTRAIN & 1.000 & 0.766 & 0.518 & 0.531 & 0.975 & 0.577 & 0.862 & 0.692 & 0.611 \\
LOCALTRAIN & 0.766 & 1.000 & 0.661 & 0.654 & 0.891 & 0.723 & 0.890 & 0.806 & 0.743 \\
LONGBUS & 0.518 & 0.661 & 1.000 & 0.653 & 0.597 & 0.898 & 0.812 & 0.870 & 0.884 \\
LOCALBUS & 0.531 & 0.654 & 0.653 & 1.000 & 0.604 & 0.919 & 0.827 & 0.823 & 0.787 \\
TRAIN & 0.975 & 0.891 & 0.597 & 0.604 & 1.000 & 0.660 & 0.920 & 0.770 & 0.691 \\
BUS & 0.577 & 0.723 & 0.898 & 0.919 & 0.660 & 1.000 & 0.902 & 0.930 & 0.916 \\
TRANSPORT & 0.862 & 0.890 & 0.812 & 0.827 & 0.920 & 0.902 & 1.000 & 0.928 & 0.876 \\
AUTO & 0.692 & 0.806 & 0.870 & 0.823 & 0.770 & 0.930 & 0.928 & 1.000 & 0.927 \\
CS & 0.611 & 0.743 & 0.884 & 0.787 & 0.691 & 0.916 & 0.876 & 0.927 & 1.000 \\
\hline
\end{tabular}

Notes: 1. Names and description of indicators - see chapter 4.1

2. Public transport indicator 2006, AUTO 2005, CS 2001

3 . All correlations are significant at the level 0.01 (2-tailed).

Source: electronic IDOS timetable, Transport census ŘSD ĊR, ČSÚ, Hampl 2005

AUTO, the index expressing the quantity of motor vehicles passing through the centre during for 24 hours on an "average" day in 2005 , is, of course, the transport group exhibiting the highest level of hierarchization. The degree of hierarchization in this group is even higher than the level of hierarchization according to aggregate bus connections and exhibits, to a certain degree, nodal conditionality. However, it still does not reach the development extent of the complex hierarchization of centres.

The mutual "closeness" of hierarchies according to the various indicators used was evaluated by a correlation analysis (see Tab. 2). The generally high association of monitored hierarchies can be characterized as expected, because transport hierarchy is a partial component of the complex hierarchy. As assumed, both monitored types of the transport system display a different relation. The importance of bus transport is correlated with the complex importance of centres more closely than the importance of rail transport. The cause for this is primarily the higher nodal conditionality of the organization of bus transport mentioned. Association of partial transport characteristics with $C S$ is significantly lower than in the case of relevant aggregate characteristics. It can, however, be confirmed that the number of longdistance connections is in both cases less correlated with $C S$ values than is the number of local connections (in the case of express train connections it is the lowest correlation at all). In terms of the finding that groups of longdistance connections exhibit, in general, more extensive hierarchization, their low correlation with the complex importance group, showing the most extensive hierarchization, is somewhat surprising. Especially in rail transport, a repeated difference between the hierarchy of transport nodes and the hierarchy of transport networks is expressed here. Another conditioning factor is the fact that the importance of local transport is more inclined to nodal organization and that rail transport is more specialized in long-distance transport. A consequence is that the hierarchy of centres, in terms of rail transport, "must" correspond to the complex settlement hierarchy less "precisely" overall than does the hierarchy in terms of bus transport. Table 2 further verifies that the relation of long-distance bus connections and train connections is less correlated than the relation of local bus and train connections. It shows a certain complimentary nature of long-distance bus 
Tab. 3 - Paired correlations of transport characteristics and complex size - the 12 most significant centres

\begin{tabular}{|l|c|c|c|c|c|c|c|c|c|}
\hline & $\begin{array}{c}\text { LONG- } \\
\text { TRAIN }\end{array}$ & $\begin{array}{c}\text { LOCAL- } \\
\text { TRAIN }\end{array}$ & $\begin{array}{c}\text { LONG- } \\
\text { BUS }\end{array}$ & $\begin{array}{c}\text { LOCAL- } \\
\text { BUS }\end{array}$ & TRAIN & BUS & $\begin{array}{c}\text { TRANS- } \\
\text { PORT }\end{array}$ & AUTO & CS \\
\hline LONGTRAIN & 1.000 & 0.833 & $0.663^{*}$ & $0.651^{*}$ & 0.977 & 0.712 & 0.868 & 0.799 & 0.760 \\
LOCALTRAIN & 0.833 & 1.000 & 0.909 & 0.736 & 0.931 & 0.898 & 0.958 & 0.933 & 0.934 \\
LONGBUS & $0.663^{*}$ & 0.909 & 1.000 & $0.702^{*}$ & 0.784 & 0.934 & 0.912 & 0.943 & 0.926 \\
LOCALBUS & $0.651^{*}$ & 0.736 & $0.702^{*}$ & 1.000 & 0.710 & 0.910 & 0.864 & 0.817 & 0.845 \\
TRAIN & 0.977 & 0.931 & 0.784 & 0.710 & 1.000 & 0.812 & 0.938 & 0.883 & 0.858 \\
BUS & 0.712 & 0.898 & 0.934 & 0.910 & 0.812 & 1.000 & 0.964 & 0.959 & 0.963 \\
TRANSPORT & 0.868 & 0.958 & 0.912 & 0.864 & 0.938 & 0.964 & 1.000 & 0.972 & 0.963 \\
AUTO & 0.799 & 0.933 & 0.943 & 0.817 & 0.883 & 0.959 & 0.972 & 1.000 & 0.966 \\
KS & 0.760 & 0.934 & 0.926 & 0.845 & 0.858 & 0.963 & 0.963 & 0.966 & 1.000 \\
\hline
\end{tabular}

Notes: 1 . Names and description of indicators - see chapter 4.1

2. Public transport indicator 2006, AUTO 2005, CS 2001

3. Correlations significant at the level 0.05 (2-tailed) are signed by *, all other are significant at the level 0.01 (2-tailed).

Source: electronic IDOS timetable, Transport census ŘSD ČR, ČSÚ, Hampl 2005

and train transport, which is ,by the way, confirmed primarily with the fact, that by aggregating transport characteristics, the degree of association of the transport hierarchy and complex hierarchy increases.

The number of vehicles passing through (AUTO) shows a close association with the complex importance of centres, similar to the BUS index, confirming that automobile transport, as the most flexible transport mode, will correspond the most to the complex importance of centres. At the same time, the $A U T O$ index has a significantly closer relationship with local connections (both bus and train) than with the long-distance connections, which indicates the dominant use of cars for ensuring functions of centres at the microregional level, i.e. for supplementing the frequently insufficient public transport services.

The comparison of monitored transport hierarchies mentioned with the rank size rule led to a conclusion that the hierarchical principle is most extensively developed, in their case, at the "upper levels" of the hierarchy, although the hierarchization as whole is strongly conditioned, especially by the relatively weakly differentiated "lower levels" of the hierarchy. It seems, therefore, useful to make a correlation analysis not only for the entire group of 144 centres, but also within its subdivided, hierarchical categories. For this reason, Table 3 provides the values of paired correlations of the indicators used only for the group of 12 centres of meso-regional importance and for the macro-regional centre, Czechia's regional capitals with the exception of Jihlava. A comparison of values for the entire group and its hierarchically most significant portion shows above all a general increase in the closeness of correlations. The relation of aggregate characteristics and partial indicators is stronger, especially in the case of rail transport. This shows the impact of the position of centres in the transport network, because in the case of regional capitals, the position within road and rail networks is relatively equal. However, a higher nodal conditionality of bus and automobile transport, manifested by a higher correspondence with the complex hierarchy, remained in force. With the largest centres, harmony between the hierarchy of transport nodes and transport networks, which is reflected in the high degree of correspondence between the transport and complex hierarchy 
(the greatest nodes of the networks hierarchy are decisive) can be pointed out. An increase in the level of association between the transport and complex hierarchies with aggregating the characteristics again verifies the complementary nature of both types of public transport monitored in the centres. At the same time, the level of specialization in bus and rail transport between local and long-distance transport has decreased and it can be said that the largest centres have complex transport services.

\section{Conclusion}

The analyses performed have verified the assumed mutual size conditionality of the transport and complex importance of centres, which is manifested by a close correlation of general characteristics. At the same time, the significant impact of the position of centres in transport networks was clearly expressed, with bus and automobile transport being the most closely associated with the complex hierarchy, because, in contrast to rail transport, they are less determined by their transport network and can respond "more independently" to the current demand for transport. The position in networks also leads, to a certain degree, to the transport specialization of centres, when important centres of rail transport also have a high number of long-distance connections and bus transport is more focused on providing links at the local level. Both types of public transport are thus complementing one another. Automobile transport is, in terms of transport distance, probably rather autonomous, of course with dominant use in local transport.

A comparison of relations within the entire group of 144 centres of microregional importance and of the results for the 12 most significant centres has shown that the impact of transport networks and the specialization of various types of transport are less evident in this case. An explanation can be found in the relatively equalized position of regional capitals in both types of transport networks.

Further monitoring should be aimed primarily at the situation of centres at "lower levels" of the hierarchy, which exhibit only low levels of hierarchization (as a consequence of planned transport services and of efforts to ensure, at least, spatially inclusive transport availability along with other contributing causes) and in such circumstances, the transport importance of centres corresponds to a lesser degree with their complex importance. The main public transport mode there is bus transport and, primarily, individual automobile transport, which probably compensates for insufficient public transport services. The number of persons who because they are not able to drive their own car, are placed in a situation of "transport exclusion" may therefore increase. This issue, connected with the significant applications for transport policy can become a hot topic for further transport geography research.

\section{References:}

BLAŽEK, J. (2001): Velké firmy a subjekty progresivního terciéru jako aktéři regionálního rozvoje v České republice. In: Hampl a kol. (ed.): Regionální vývoj: Specifika české transformace, evropská integrace a obecná teorie. Katedra sociální geografie a regionálního rozvoje, PřF UK, Praha, pp. 227-249.

BRYAN, J. et al. (1997): Road infrastructure and economic development in the periphery: the case of A55 improvements in North Wales. Journal of Transport Geography, 5, No. 4, Elsevier, London, pp. 227-237. 
BRUINSMA, F., RIETVELD, S. (1998): Is Transport Infrastructure Effective? Springerverlag, Berlin - Heidelberg, $383 \mathrm{p}$.

ČERMÁK, Z. (2001): Vývoj migrační mobility v devadesátých letech v České republice. In: Hampl a kol. (ed.): Regionální vývoj: Specifika české transformace, evropská integrace a obecná teorie. Katedra sociální geografie a regionálního rozvoje, PřF UK, Praha, pp. 87-98.

DICKEN, P., LLOYD, P. E. (1992): Location in Space: Theoretical Perspectives in Economic Geography, HarperCollins, UK, p. 431.

FARRINGTON, J., FARRINGTON, C. (2005): Rural accessibility, social inclusion and social justice: towards conceptualisation. Journal of Transport Geography, 13, Elsevier, London, pp. 1-12.

HAGGETT, S., CHORLEY, S. J. (1969): Network Analysis in Geography. Edward Arnold, London, $347 \mathrm{p}$.

HAMPL, M. a kol. (1996): Geografická organizace společnosti a transformační procesy v České republice. Katedra sociální geografie a regionálního rozvoje, PřF UK, Praha, 396 p.

HAMPL, M., MÜLLER, J. (1996): Komplexní organizace systému osídlení. In: Hampl, M. a kol.: Geografická organizace společnosti a transformační procesy v ČR. Katedra sociální geografie a regionálního rozvoje, PřF UK, Praha, pp. 53-89.

HAMPL, M. (2004): Současný vývoj geografické organizace a změny v dojíždoe za prací a do škol v Česku. Geografie-Sborník Ceské geografické společnosti, 109, No. 3, pp. 205-222.

HAMPL, M. (2005): Geografická organizace společnosti v České republice: Transformační procesy a jejich obecný kontext. Katedra sociální geografie a regionálního rozvoje, PřF UK, Praha, 148 p.+maps.

HƯRSKY, J. (1978): Regionalizace České socialistické republiky na základě spádu osobní dopravy. Studia Geographica, 59, Geografický ústav ČSAV, Brno, 182 p.

JEŘABEK, M., MARADA, M. (2003): Geografická analýza nepř́ímých dopadů dálnice D8. In: Lehovec, F. a kol.: Komplexní hodnocení užitku výstavby dopravní infrastruktury. Katedra silničních staveb, Fakulta stavební ČVUT, Praha, 23 p.

KRAFT, S. (2007): Regionální hromadná doprava Karlovarského kraje. Diplomová práce, katedra geografie, Pedagogická fakulta Jihočeské Univerzity v Českých Budějovicích, České Budějovice, 85 p. + supl.

KVĚTON, V. (2006): Hodnocení dopravních možností obyvatel: analýza okresů Česka a mikroregionální pohled. Diplomová práce. Katedra sociální geografie a regionálního rozvoje PřF UK, Praha, 103 p. + supl.

LEHOVEC, F. a kol. (2003): Komplexní hodnocení užitku výstavby dopravní infrastruktury. Katedra silničních staveb, Fakulta stavební ČVUT, Praha, 73 p.

LUOMA et al. (1993): The threshold gravity model and transport geography. Journal of Transport Geography, 1, No. 4, Elsevier, London, pp. 240-247.

MARADA, M. (2003a): Dopravní infrastruktura a hierarchie středisek v českém pohraničí. Geografie-Sborník ČGS, 108, No. 2, Česká geografická společnost, Praha, pp. 130-145.

MARADA, M. (2003b): Dopravní hierarchie středisek v Česku: vztah k organizaci osídlení. Disertační práce. Katedra sociální geografie a regionálního rozvoje PřF UK, Praha, 116 p.

MARADA, M. (2006): Dopravní vztahy v Pražském městském regionu. In: Ouředníček, M. (ed.): Sociální geografie Pražského městského regionu. Univerzita Karlova v Praze, Přírodovědecká fakulta, katedra sociální geografie a regionálního rozvoje, Praha, pp. 64-78.

MARADA, M. (2006): Vertikální a horizontální dopravní poloha stredisek osídlení Ceska. In: Kraft, S., Mičková, K., Rypl, J., Švec, P., Vančura, M.: Česká geografie v evropském prostoru, elektronický sborník prríspěvků (CD-ROM) z XXI. sjezdu České geografické společnosti, katedra geografie, Pedagogická fakulta, Jihočeská univerzita v Ceských Budějovicích, pp. 169-174.

MARADA, M., HUDECEK, T. (2006): Accessibility of peripheral regions: A case of Czechia. EUROPA XXI - Regional periphery in central and eastern Europe, No. 15, Polish Academy of Sciences, Stanisłav Leszczycki Institute of Geography and Spatial Organization, Warszawa, pp. 43-49.

McDONAGH, J. (2006): Transport policy instruments and transport-related social exclusion in rural Republic of Ireland. Journal of Transport Geography, 14, Elsevier, London, pp. 355-366.

NUTLEY, S. (1998): Rural Areas: Accessebility Problem. In: Hoyle, B., Knowles, R. (eds): Modern Transport Geography, 2nd rev. ed., Wiley and sons, Chichester, pp. 185-215.

OUŘEDNÍČEK, M., ed. (2006): Sociální geografie Pražského městského regionu. Univerzita Karlova v Praze, Přírodovědecká fakulta, katedra sociální geografie a regionálního rozvoje, Praha, $160 \mathrm{p}$. 
PALMA de, A., ROCHAT, D. (2000): Mode choices for trips to work in Geneva: an empirical analysis. Journal of Transport Geography, 8, Elsevier, London, pp. 43-51.

PRESTON, J. (2001): Integrating transport with socio-economic activity - a research agenda for the new millennium. Journal of Transport Geography, 9, Elsevier, London, pp. 13-24.

RÖLC, R. (2004): Hierarchie osídlení a dopravní systémy: specifika měřítkové diferenciace na př́ikladě České republiky Disertační práce, katedra sociální geografie a regionálního rozvoje PřF UK, Praha, 166 p.+supl.

ŘEHÁK, S. (1992): Śídelně dopravní model ČSFR a jeho územní souvislosti. Geografie-Sborník ČGS, 44, No. 1, Česká geografická společnost, Praha, pp. 59-72.

SEIDENGLANZ, D. (2007): Dopravní charakteristiky venkovského prostoru. Disertační práce, Přírodovědecká fakulta, Masarykova univerzita v Brně, Brno, 171 p.+příl.

URBÁNKOVÁ, J., OUŘEDNÍČEK, M. (2006): Vliv suburbanizace na dopravu v Pražském městském regionu. In: Ouředníček, M. (ed.): Sociální geografie Pražského městského regionu. Univerzita Karlova v Praze, Př́rodovědecká fakulta, katedra sociální geografie a regionálního rozvoje, Praha, pp. 79-95.

VONDRÁČKOVÁ, P. (2006): Vliv dálnice D8 na regionální rozvoj: Percepce veřejnou správou, obyvateli a firmami. Diplomová práce, katedra sociální geografie a regionálního rozvoje PřF UK, Praha, 87 p.+supl.

Elektronický jízdní řád IDOS 1999/2000. CHAPS, Brno.

Sčítání dopravy na dálnicích a hlavních silnicích Č̀R v roce 1990 a 2005. Analogová a internetová verze výsledků (www.rsd.cz), Ředitelství silnic a dálnic ČR, Praha.

\section{Shrnutí}

\section{DOPRAVA A GEOGRAFICKÁ ORGANIZACE SPOLEČNOSTI: PŘÍPADOVÁ STUDIE ČESKA}

Také o geografii dopravy lze konstatovat několikrát opakovaný názor M. Hampla (např. Hampl 2004), že geografický výzkum se zaměřuje spíše na studium „geografické organizace vývoje“ a méně už na potřebné zobecňující studium „vývoje geografické organizace“. Přitom „...je potřebné hledat odpovědi na otázky: jak se mění charakter koncentračních procesů, jak se vyvíjí sídelní hierarchie, jak se mění středisková působnost měst ve smyslu rozsahovém i funkčním, resp. kvalitativním.“ (s. 206) Při zohlednění dopravněgeografických aspektů lze zmíněnou problematiku zjednodušeně rozčlenit do tř́i okruhư. Zřejmý je vliv dopravních faktorů na proměny koncentrace pracovních příležitostí a progresivních aktivit, tedy na procesy vedoucí $\mathrm{k}$ prohlubování sídelní hierarchie. Vlastní dopravní význam jednotlivých středisek - jak $\mathrm{z}$ hlediska postavení $\mathrm{v}$ dopravních sítích, tak $\mathrm{z}$ hlediska intenzity dopravy - je ovšem výsledkem vztahů střediska $\mathrm{s}$ jeho mikroregionálním zázemím a také vztahů mezistřediskových, které probíhají v rámci jednotlivých regionálních úrovní středisek, ale i mezi středisky stejné úrovně navzájem. Hierarchicky výše položená střediska pak kumulují své funkce (i dopravní) na různých regionálních řádech. Problematikou mezistřediskových vztahů a vztahů středisko-zázemí jsou dány dva základní okruhy diskutované problematiky, třetím je pak vlastní vztah mezi výslednou dopravní a komplexní hierarchií středisek. Z důvodu omezeného rozsahu článku je empiricky blíže vyhodnocen pouze okruh třetí na příkladu hierarchie hlavních středisek osídlení Česka.

Vzájemné ovlivnění dopravní a komplexně-sídelní hierarchie středisek lze předpokládat v několika aspektech. Za prvé je to samozřejmá velikostní podmíněnost dopravní a komplexněsídelní hierarchie. Tato podmíněnost je jistě pozitivní, má souhlasné vývojové tendence a zjištěná asociace dopravního významu středisek $\mathrm{s}$ významem komplexním bude pravděpodobně velmi těsná. Častým důvodem rozdílů v dopravní a geografické poloze sídel, a tak narušením souhlasnosti obou hodnocených hierarchií, je odlišná dopravní poloha střediska $\mathrm{v}$ dopravní síti. Ta se projevuje také $\mathrm{z}$ hlediska struktury dopravy ve středisku, konkrétně $\mathrm{v}$ poměru vlakových a autobusových spojů i v poměru spojů mezinárodních, dálkových vnitrostátních a místních. Dopravní poměry ve středisku z hlediska struktury dopravních prostředků jsou do jisté míry určeny také charakterem zázemí střediska (řídce zalidněná území jsou hưr̆e obsluhována veřejnou hromadnou dopravou a jsou více odkázána na individuální automobilizaci).

Vzhledem ke zmíněné velikostní podmíněnosti můžeme předpokládat silnou asociaci hierarchií obou typů. Parciální dopravní systémy (autobusová, automobilová a železniční doprava) ovšem budou asociovány s komplexní hierarchií různou měrou. $\mathrm{Z}$ důvodu plánované, „plošné“ obslužnosti obyvatelstva autobusovou dopravou a menší determinace silniční dopravy 
sítěmi bude těsnější vztahy ke komplexní hierarchii vykazovat doprava autobusová a automobilová, než doprava železniční, která svoji vázaností na historické železniční sítě projevuje jakousi „liniovou“ diferenciaci $\mathrm{s}$ větším zaměřením na dálkovou dopravu. $\mathrm{Z}$ obdobných důvodů se $\mathrm{z}$ dopravních charakteristik bude mírou hierarchizace nejvíce přibližovat komplexní hierarchii automobilová doprava a doprava autobusová.

Empirické hodnocení bylo provedeno na souboru 144 středisek osídlení, kterým podle sociogeografické regionalizace k roku 2001 (Hampl 2005) přísluší alespoň mikroregionální význam. Význam, resp. rozsah veřejné osobní železniční a autobusové dopravy ve střediscích byl hodnocen pomocí počtu spojů odjíždějících ze střediska, a to ve středu dne 24 . května 2006 („běžný“ všední den). Zároveň byly rozlišovány spoje místní a dálkové. Kromě těchto parciálních ukazatelů byly vytvořeny agregátní ukazatele VLAK, BUS a DOPRAVA, ve kterých byla počtu dálkových a vlakových spojů přisouzena vyšší váha. Druhým způsobem hodnocení dopravního významu středisek bylo vyčíslení intenzity automobilové dopravy, která byla stanovena jako součet celkových dopravních intenzit v bodech Sčítání dopravy (RSD 2005) ležících nejblíže středisku. Komplexní význam středisek byl hodnocen ukazatelem komplexní velikosti středisek (KV) za rok 2001 (Hampl 2005).

Podle předpokladu je celková dopravní hierarchie středisek $\mathrm{z}$ hlediska veřejné hromadné dopravy (ukazatel DOPRAVA) vyvinuta podstatně slaběji než nejrozvinutější hierarchie komplexní sídelní (tab. 1). Dále lze konstatovat, že z hlediska dálkové dopravy jsou střediska pochopitelně více hierarchizována než z hlediska dopravy lokální. Přes celkově nízkou hierarchizaci dopravního významu je patrné, že střediska z hlediska vybavení autobusovou dopravou jsou hierarchizována výrazněji než z hlediska obslužnosti dopravou železniční. Jinými slovy, vybavení středisek autobusovou dopravou je podmíněno spíše hierarchií nódů, zatímco železniční obslužnost středisek je dána spíše hierarchií dopravních sítí či os. Nejvíce hierarchizovaným dopravním souborem je AUTO a vykazuje tak rovněž určitou nodální podmíněnost. Rozvinutosti komplexní hierarchizace středisek však samozřejmě rovněž nedosahuje.

Naznačenou míru souladu hierarchií podle jednotlivých ukazatelů statisticky potvrzují hodnoty párových korelací (viz tab. 2), která také naznačuje určitou doplňkovost dálkové autobusové a vlakové dopravy. Tu potvrzuje především skutečnost, že agregací dopravních charakteristik se míra asociace dopravní hierarchie a hierarchie komplexní zvyšuje. Vysokou asociaci s komplexním významem středisek (jako agregát BUS) vykazuje počet projíždějících vozidel (AUTO), což potvrzuje, že automobilová doprava jako nejflexibilnější dopravní mód bude nejvíce odpovídat komplexnímu významu center. Zároveň má ukazatel AUTO výrazně těsnější vztah ke spojům místním (autobusovým i vlakovým) než ke spojům dálkovým, což naznačuje dominantní využívání automobilů $\mathrm{k}$ zajištění funkcí středisek na mikroregionální úrovni, tedy $\mathrm{k}$ doplnění často nedostatečné obslužnosti hromadnou dopravou.

Srovnání sledovaných dopravních hierarchií s pravidlem velikostního pořadí měst vedlo k závěru, že hierarchický princip je u nich nejvíce rozvinut na „vrchních patrech“ hierarchie, avšak celková hierarchizace je výrazně podmíněna především relativně málo diferencovanými „spodními patry“ hierarchie. Jako účelné se proto jevilo provedení korelační analýzy nejen za celý soubor 144 středisek, ale také v rámci dílčích kategorie 12 středisek mezoregionálního významu a střediska makroregionálního, tj. krajských měst Česka bez Jihlavy (tab. 3). V případě největších středisek lze hovořit o souladu hierarchie dopravních nódů a dopravních sítí, který se odráží ve vysoké souhlasnosti dopravní a komplexní hierarchie (největší nódy hierarchii sítí určují). Zároveň došlo k rozvolnění specializace autobusové a železniční dopravy na místní a dálkové přepravy a lze konstatovat, že největší střediska jsou dopravně obsluhována komplexním způsobem.

Obr. 1 - Sociogeografické mikroregiony a jejich střediska v Česku (2001). Střediska vyššího významu - makroregionálního (Praha) a mezoregionálního (krajská města bez Jihlavy) - jsou popsána. Ostatní mikroregionální centra jsou uvedeny v abecedním pořadí.

Author is with Charles University in Prague, Faculty of Science, Department of Social Geography and regional Development, Albertov 6, 128 43, Praha 2, Czechia; e-mail: marada@natur.cuni.cz. 